\title{
"Mompox. EI Síndico Procurador, Francisco de la Bárcena Posada, pide sanción para los desmanes de los bogas, que hacen el tráfico fluvial del Magdalena, de Honda a la nominada villa, tocando en Zaragoza, Cáceres y otros puertos. Años de 1805"'1
}

\author{
Muriel Vanegas Beltrán ${ }^{2}$ (D), Adineth Vargas Hernández 3 (i) \\ ${ }^{1}$ Universidad de Cartagena-Colombia \\ ${ }^{2}$ Universidad Pedagógica y Tecnológica de Colombia
}

Para citaciones: Vanegas, M., Vargas, A. (2020). “Mompox. El Síndico Procurador, Francisco de la Bárcena Posada, pide sanción para los desmanes de los bogas, que hacen el tráfico fluvial del Magdalena, de Honda a la nominada villa, tocando en Zaragoza, Cáceres y otros puertos. Años de 1805". El taller de la Historia, 12(1), 223-247. DOI: $\underline{10.32997 / 2382-4794-v o l .12-n u m .1-2020-3208}$

Editor: Sergio Paolo Solano. Universidad de Cartagena-Colombia.

Copyright: $\odot$ 2020. Vanegas, M., Vargas, A. Este es un artículo de acceso abierto, distribuido bajo los términos de la licencia https://creativecommons.org/licenses/by-nc$\underline{\mathrm{sa} / 4.0 / \text { la cual permite el uso sin restricciones, }}$ distribución y reproducción en cualquier medio, siempre y cuando que el original, el autor y la fuente sean acreditados.

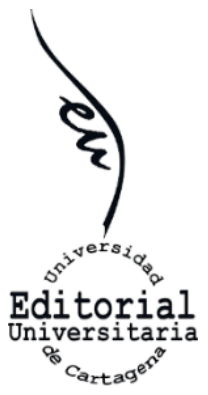

\section{PRESENTACIÓN}

Los bogas eran una grupo de trabajadores ligados a la historia del río Magdalena y sus afluentes. Este río era la arteria fluvial que vinculaba al mundo andino con los puertos del Caribe neogranadino y colombiano, y al mundo exterior con los mercados andinos. Objeto de la literatura, ${ }^{4}$ de cuadros de costumbres, ${ }^{5}$ de crónicas de viajeros nacionales y extranjeros, ${ }^{6}$ de noticias de periódicos y de informes oficiales, tanto del período colonial como del siglo XIX, durante varios siglos el boga fue ese otro, el sujeto-objeto de las primeras relaciones que entablaron funcionarios, intelectuales y miembros de las elites con el mundo y las sociedades fluviales de los ríos y caños que comunicaban al interior andino con los puertos del Caribe neogranadino y a los extranjeros que se movilizaban por esos ríos con destino al interior del país. Y exceptuando a uno que otro viajero (por ejemplo el socialista utópico francés Elysee Reclus) las imágenes que se construyeron sobre sus labores y sus comportamientos para nada favorecen a los bogas, a tal punto, que, hasta hace pocos años, en Barranquilla, principal puerto fluvial sobre el río Magdalena y epicentro de la navegación fluvial (tanto impelida por fuerza humana como por máquinas de vapor), era usual que para calificar a una persona por sus malos hábitos (vocabulario, además, formas en la mesa, etc.) se le dijera, "pareces un boga". ${ }^{7}$ El término fue cayendo en desuso, hasta el punto que el padre Pedro María Revollo no lo incluyó en su diccionario de Costeñismos Colombianos, publicado en 1940.

\footnotetext{
${ }^{1}$ Agradecemos a Karen Victoria Orozco, Whiston Pérez y Yorleth Santiago, estudiantes del Programa de Historia y becarios del Laboratorio de Investigación Histórica en Estudios Coloniales, la colaboración prestada es la transcripción de este documento.

${ }^{2}$ Doctora en Ciencias de la Educación. Investigadora, Instituto Internacional de Estudios del Caribe. Profesora asociada Universidad de Cartagena. mvanegasb@ unicartagena.edu.co

${ }^{3}$ Historiadora. Maestría en Patrimonio Cultural UPTC. adineth.vargas@ uptc.edu.co

${ }^{4}$ David Peñas Galindo (prólogo y compilación), Candelario Obeso... popular y desconocido. Cantos populares de mi tierra, Mompox, Eds. Pluma de Mompox, 2007, pp. 33-35, 45-51.

${ }^{5}$ Manuel María Madiedo, "El boga del Magdalena", en Museo de cuadros de costumbres: variedades y viajes, tomo I, Bogotá, Banco Popular, 1973, pp. 13-21.

${ }^{6}$ Ver la compilación de viajeros que transitaron por el río Magdalena realizada por Aníbal Noguera, (ed.), Crónica grande del río de la Magdalena, 2 tomos, Bogotá, Fondo Cultural Cafetero, 1975.

7 “Boga. Lo aplicamos con frecuencia para tachar a una persona grosera y mal educada...”, Adolfo Sundheim, Vocabulario costeño. O lexicografía de la región septentrional de la República de Colombia, Barranquilla, Gobernación del Atlántico, 1994 , p. 102
} 
Este trabajador cuenta con algunos estudios históricos. A mediados del siglo XX el español Antonio Ybot León se interesó en los bogas y el bogaje durante el periodo colonial. ${ }^{8}$ Años después, fue la obra de Orlando Fals Borda, en especial su libro Mompox y Loba (1979) el que empezó a mostrar a esta figura sobre cuyo brazos se apoyó el tráfico de personas y mercaderías y parte del progreso nacional. Pocos años después, David Peñas Galindo volvió sobre el tema, estudiando al boga como expresión del cruce triétnico del bajo curso del río Magdalena. ${ }^{9}$ Con el despegue de la moderna historiografía sobre la región Caribe colombiana el boga ocupó la atención de varios historiadores, ${ }^{10}$ y desde los estudios literarios y socio-culturales también se han adelantado investigaciones. ${ }^{11}$

Visto en perspectiva temporal investigaciones recientes insinuaron $\mathrm{y}$ mostraron posibilidades para sacar el tema de los bogas de la recurrente queja de los usuarios de la navegación en champanes y bongos. Una insinuación inicial señaló la necesidad de definir si el bogaje, la relación patronos-bogas y embarcación era personal, es decir, si cada embarcación eran propiedad del patrón o si se trataba de una actividad empresarial en la que participaban personas que concentraban cantidades de embarcaciones. También se ha mostrado que los trabajadores modernos de la navegación fluvial a vapor tuvieron como matriz a los bogas. Y de igual forma, que estos, unidos con los cargueros desarrollaron formas de organización laboral que estuvieron en el epicentro de los conflictos sociales que marcaron la vida de los puertos fluviales y marítimos colombianos durante la primera mitad del siglo XX. ${ }^{12}$

El documento que presentamos a los lectores es un informe de las autoridades de Mompox que llegó a las altas esferas del virreinato en el que se presentan quejas contra la prestación del servicio del transporte por parte de los bogas. Más allá de presentar la habituales quejas contra el comportamiento de los bogas, el interés de este documento radica en que permite conocer, como estaba organizado el negocio del transporte, la participación de personas notables en este negocio y los intentos de las autoridades por regularizar la prestación de este servicio. Creemos que este documento permite colocar el tema en una perspectiva distinta a las quejas por sus comportamientos, el negocio del transporte fluvial y sus ejercitantes, los bogas, nos permita avanzar en el conocimiento de este sector de

\footnotetext{
${ }^{8}$ Antonio Ybot Leon, La arteria histórica del Nuevo Reino de Granada (Cartagena-Santa Fe 1538-1798), Bogotá, Editorial ABC, 1952.

${ }^{9}$ David Peñas Galindo, Los bogas de Mompox: historia del zambaje, Bogotá, Tercer Mundo Eds., 1988.

${ }^{10}$ Eduardo Posada, "Bongos, champanes y vapores en la navegación fluvial colombiana en el siglo XIX", en Boletín Cultural y Bibliográfico, 21, 1989, 3-13; Edgar Rey Sinning, El hombre y su rio, Santa Marta, Imp. Gutemberg, 1995.

${ }^{11}$ Ana María Ochoa, "El mundo sonoro de los bogas del Magdalena". Revista Número 28, (2008): 1-15; George Palacios, "El motivo de los "bogas" en la imaginación literaria de Jorge Isaacs y Candelario Obeso". Escritos, 18, 40, (2010): 156184; María Camila Nieto y María Riaño, Esclavos, negros libres y bogas en la literatura del siglo XIX, Bogotá, Universidad de Los Andes, 2011; Felipe Martínez, "Tránsitos por el río Magdalena: el boga, el blanco y las contradicciones del liberalismo colombiano de mediados del siglo XIX", Estudios de Literatura Colombiana, 29, (2011): 17-41.

12 Sergio Paolo Solano, Puertos, sociedad y conflictos en el Caribe colombiano, 1850-1930, Cartagena, Ministerio de Cultura/Observatorio del Caribe Colombiano, 2003; “Trabajo, formas de organización laboral y resistencia de los trabajadores de los puertos del Caribe colombiano, 1850-1930”. Revista Europea de Estudios Latinoamericanos y del Caribe/European Review of Latin American and Caribbean Studies, 88, (2010): 39-60.
} 
trabajadores y en la vida social de muchas poblaciones del río Magdalena de ese entonces.

\section{Bibliografía}

Madiedo, Manuel María, "El boga del Magdalena", en Museo de cuadros de costumbres: variedades y viajes, tomo I, Bogotá, Banco Popular, 1973, pp. 13-21.

Martínez, Felipe, “Tránsitos por el río Magdalena: el boga, el blanco y las contradicciones del liberalismo colombiano de mediados del siglo XIX", Estudios de Literatura Colombiana, 29, (2011): 17-41.

Nieto, María Camila y Riaño, María, Esclavos, negros libres y bogas en la literatura del siglo XIX, Bogotá, Universidad de Los Andes, 2011.

Noguera Aníbal, (ed.), Crónica grande del río de la Magdalena, 2 tomos, Bogotá, Fondo Cultural Cafetero, 1975.

Ochoa, Ana María, "El mundo sonoro de los bogas del Magdalena". Revista Número 28, (2008): 1-15.

Palacios, George, "El motivo de los 'bogas' en la imaginación literaria de Jorge Isaacs y Candelario Obeso". Escritos, 18, 40, (2010): 156-184.

Peñas Galindo,' David, Los bogas de Mompox: historia del zambaje, Bogotá, Tercer Mundo Eds., 1988.

Peñas Galindo, David (prólogo y compilación), Candelario Obeso... popular y desconocido. Cantos populares de mi tierra, Mompox, Eds. Pluma de Mompox, 2007.

Posada,' Eduardo, "Bongos, champanes y vapores en la navegación fluvial colombiana en el siglo XIX”, en Boletín Cultural y Bibliográfico, 21, 1989, 3-13.

Rey Sinning, Edgar, El hombre y su rio, Santa Marta, Imp. Gutemberg, 1995.

Solano, Sergio Paolo, Puertos, sociedad y conflictos en el Caribe colombiano, 18501930, Cartagena, Ministerio de Cultura/Observatorio del Caribe Colombiano, 2003.

Solano, Sergio Paolo, "Trabajo, formas de organización laboral y resistencia de los trabajadores de los puertos del Caribe colombiano, 1850-1930". Revista Europea de Estudios Latinoamericanos y del Caribe/European Review of Latin American and Caribbean Studies, 88, (2010): 39-60.

Sundheim, Adolfo, Vocabulario costeño. O lexicografía de la región septentrional de la República de Colombia, Barranquilla, Gobernación del Atlántico, 1994.

Ybot Leon, Antonio, La arteria histórica del Nuevo Reino de Granada (CartagenaSanta Fe 1538-1798), Bogotá, Editorial ABC, 1952. 


\section{"Mompox. El Síndico Procurador, Francisco de la Bárcena Posada, pide sanción para los desmanes de los bogas, que hacen el tráfico fluvial del Magdalena, de Honda a la nominada villa, tocando en Zaragoza, Cáceres y otros puertos. Años de 1805"}

Archivo General de la Nación-Colombia, Sección Colonia, fondo Mejoras Materiales, tomo 12, documento 11, folios 715 recto-750 vuelto.

El procurador general de Mompox Pide providencia para contención y castigo de las iniquidades de los Bogas [folio 716r.].

Pedimento.

Señor alcalde ordinario. El procurador sindico general ante Vuestra Merced en la forma que por derecho más haya lugar dice: que Siendo ya vicio común en los bogas de la carrera de Honda, Zaragoza, Cáceres y otros puertos situados a orillas de este rio Grande de la Magdalena y demás que toman su origen de él, el doloso arbitrio de percibir pagas dobles con diferentes nombres supuestos al tiempo que se hacen las habilitaciones y fletamentos de las embarcaciones por las personas que como dueños propios de ellas, o por recomendaciones particulares ejecutan estas operaciones bajo una buena fe; y el abandonar los buques antes de llegar a sus respectivos destinos, usurpando impunemente el estipendio que se les contribuye, perjudicando al comercio con las demoras que causan en el tránsito de los efectos que conducen, y a los amos de ellos en la pérdida del interés que sacrifican, pues rara vez vienen a lograr su reposición y sufren crecidos quebrantos por semejante razón, todo motivado a que no tienen los tales bogas bienes conocidos con que subsanar los graves perjuicios que originan con tan abominable procedimiento, pues todos ellos los que disfrutan se reduce al miserable vestal que los cubre, al instrumento de su oficio, la estera en que duermen y acaso el toldo con que se libertan de la mortificación del mosquito, ni tampoco una ley penal designada para corregirlos, y que [folio 717r.] su inalterable observancia sirva de escarmiento y contención en todos tiempos de que son suficientes ejemplares entre otros muchos que de algunos años a esta parte por su continua reiteración se han hecho bastante notorios, y pudiera notar circunstanciadamente el procurador general exponentes, los que en la actualidad ministran reos Manuel Antonio Surmay y José de la Encarnación Ochoa que se hallan presos en la real cárcel por los delitos que deja expresados: suplica a vuestra merced que por el beneficio que es consiguientes resulte al comercial público y a los dueños de las embarcaciones en que por forzosa necesidad y según la situación local de estas provincias se continua aquel con notables ventajas al erario real y se facilita el transito no solo a lo interior del Reino, sino también a todos más de los lugares de su comprensión de hacerse una justificación con los vecinos más caracterizados de este pueblo acerca de los particulares manifestados y de la necesidad que interviene de ocurrir al remedio de unos abusos que no pueden mirarse con otro aspecto que el de un robo simulado, y que el procurador que habla concibe ser peor que el de cuatrería pues cuando este se 
extingue con un solo acto, aquel se repite con mayor insolencia, por el mismo hecho que tiene de no conocérsele nombre ni aplicación hasta ahora en las leyes, el cual trasciende en daño irreparable de tercero, y se hace más grave por las circunstancias con que se ejecuta; so sirva mandarla instruir y que evacuada se le entregue original para elevarla a la [folio 717v.] superioridad que competa, e impetrar de ella una declaratoria decisiva de la pena con que deban ser castigados sin excepción alguna todos los que continúen en semejantes abusos. protestando como protesta, que a esto no le obliga ni el deseo de reponerse del perjuicio que lo ha originado el Manuel Antonio Surmay con la pérdida del corto interés de catorce pesos que percibió de su mano dolosamente por pagamento de un viaje de cuyo derecho si es necesario se desiste y aparta, ni otro particular; sino únicamente movido del bien público cuyas acciones representa por su ministerio de la mayor seguridad y aumentos del comercio, que ha protegido y mirado siempre como base fundamental de la Monarquía nuestro Augusto Soberano, no menos perjudicado por el propio ejemplar en sus rentas estancadas, como podrán certificarlo sus respectivos administradores; y finalmente para que estos delitos contra que declama no queden impunes, y la malicia de sus autores se escarmiente con todo rigor y circunspección en obsequito de la buena administración de justicia. Mompox enero veinte y dos de mil ochocientos cinco. Francisco de la Bárcena Posada.

\section{Decretos}

Mompox enero veinte y tres de mil ochocientos cinco, por presentado: como lo pide y en su consecuencia los señores Don Pedro Martínez de Pinillos regidor alcalde mayor provincial jubilado, Don José Antonio Troncoso regidor Subdecano y juez subdelegado de bienes de difuntos, Don Ramón Del Corral y Castro sargento mayor del cuerpo de cazadores de milicias urbanas, Don Manuel [folio 718r.] Herrera, y Don Joaquín Lascano administradores principales de las Reales Rentas de tabacos y aguardientes de esta villa sujetos en quienes concurren las circunstancias de poder instruir la verdad acerca de cuanto expone el señor procurador general en su antecedente pedimento los tres primeros por ser dueños de champanes y su notorio giro en el comercio, y los otros dos por los muchos que por cuenta de las rentas que administran se habilitan para honda y otros puertos para conducir de tabacos y harinas, certifiquen a continuación cuanto les conste pasándoseles por su orden este expediente y fecho entréguese a la parte para que use de su derecho como le convenga.

Melchor Sáenz Ortiz. Antonio de los Santos Muñoz

Certificación.

Certifico: que habiendo solicitado por la persona del señor procurador general Don Francisco de la Bárcena Posada para notificarle el proveído antecedente se me informó hallarse fuera de esta villa en la feria de Magangué. y para que así conste pongo la presente que firmo en Mompox a veinte y cuatro de enero de mil ochocientos y cinco años.

Antonio de los Santos Muñoz

Notificación. 
En nueve de febrero habiéndose tenido noticia haber regresado a esta villa en señor procurador Sindico General Don Francisco de la Bárcena Posada se le hizo saber el proveído antecedente y lo firmó de que doy fe. Francisco de la Bárcena Posada.

Otra

En la tarde de este día se hizo saber lo proveído al señor regidor Alcalde Mayor Provincial jubilado Don Pedro Martínez de Pinillos cual impuesto y en su poder dejo este expediente para los fines que en él se indican cuyo recibo firma por [folio 718v.] separado doy fe. Pedro Martínez de Pinillos.

Certificación.

Don Pedro Martínez de Pinillos vecino de esta villa y regidor alcalde mayor provincial jubilado por $\mathrm{Su}$ Majestad habiéndome impuesto de la representación del señor procurador general que antecede para que se reciba la debida información sobre los particulares que contiene, inteligenciado debo decir por mi parte: que es efectivo y cierto todo cuanto dicho procurador expone relativo al vicio común que experimentamos en los bogas de la carrera de Honda y demás al tiempo de la habilitación de los champanes recibiendo la paga de uno, dos y tres viajes a un tiempo con el arbitrio de mudar sus nombres y las más veces semejantes bogas no cumplen su viaje en champan alguno; y otros al medio o principios de la navegación abandonan la embarcación haciendo fuga para retornar a esta villa con el fin de reiterar sus engaños y tener con que sostener sus vicios por el poco temor que han tenido a la justicia, cuyos hechos lo han acreditado infinitos y notorios ejemplares el perjuicio y daño que se sigue de semejantes libertinos acontecimientos se deja comprender a primera reflexión pues apenas habrá alguno que haya transitado por estos ríos para el Reino que no respire en sentimiento de haber experimentado estos ejemplares con propio daño en la demora de su viaje igualmente que a los dueños de los botes y champanes con la perdida de respectivas pagas por la fuga de muchos, así mismo que por la detención de sus embarcaciones en las poblaciones de transito hasta reponer los bogas fugitivos, y aun estando completos [folio 719r.] se detienen por su voluntad considerable tiempo siendo necesario en dichos lugares reponer nuevamente a todo costo los víveres que su demora han consumido de todo lo cual se sigue hacerse tan hostigosa la navegación de tener y habilitar champanes que refría el ánimo a ejercitarla al que los tiene y por mi parte prefiero el partido de arreglar diariamente los dos champanes que tengo, y no el de habilitarlos, por excusar el ilegal trato de los bogas con que indisponen el ánimo y por la que respecta al comercio, este sufre no solo el recargo de fletes en su cargamento proporcionado al mayor coste que ocasionan las respectivas pagas de los bogas por los fugitivos, aumento de bastimentos y demora de champanes, cuya detención en los viajes ocasiona el mayor atraso y perjuicio en la conducción de los cargamentos y frutos del Reino en tales términos que retrae a muchos del comercio no solo de muchas contratas de poner por tiempo determinado los cargamentos en los puertos de su embarque sino que aún se excusan y limitan en mucha parte a la compra y acopios de los frutos del Reino por la dificultad que se toca en la navegación para su transporte hasta los puertos marítimos, como a mí y a otros muchos le acontece y de lo 
cual se sigue se menor caso incomparable al comercio a la agricultura y al real oficio a semejantes males no preveo otro principio u origen que el arbitrio doloso de los bogas en recibir repetidas pagas a un tiempo, la facilidad de hacer fuga cuando quieren, y detener la embarcación en las poblaciones del tránsito por el tiempo de su voluntad, y en ínterin saciar sus vicios que cada día aumentan por el [folio 719v.] poco o ningún respecto que tienen a las justicias por cuanto estas no se atreven a aplicarles el pronto castigo merecido por sus delitos ínterin no proceda pedimento de parte para el correspondiente sumario por escrito y substanciada en forma la causa, pasarla al letrado para que dictamine la pena que corresponde, y como para observar semejantes formalidades tengan que gastar las partes muchos pesos y su atención que necesitan aplicar a su negocio y por otra parte prever muy dilatado el castigo hasta evacuar la causa con todas sus formalidades; al mismo tiempo los jueces que se hallan embarazados de otros muchos asuntos en su judicatura procurar omitir semejantes causas de oficio conviniendo a la pronta transacción de las partes, que se contentan con tal que el boga delincuente se obligue a pagar en viajes de que resulta quedar los delitos impunes y los bogas con menos temor y cuidado para su reincidencia. lo cual no acontecería y se lograría el pronto remedio a tantos daños y delitos continuados, si luego que a pedimento de los interesados aprendieren tales bogas delincuentes las justicias y estas se hallasen con facultades para recibir pronta y verbal información con la que resultando justificado o confesado por los bogas y acreditado por una certificación del escribano de haber recibido diferentes pagas a un tiempo, o quedado se escondía al día señalado de salir la embarcación, o de haber hecho fuga en el transito sin cumplir su viaje, o multado con desvergüenza o amenazas a los pasajeros que conducen, se mandasen aplicar veinte y cinco azotes con un[folio 720r.] rejo torcido en las espaldas desnudas y amarra en la reja de la cárcel que le sirviere de castigo correccional por la primera vez, y quedasen apercibidos en caso de reincidencia al aumento de castigo o a un presidio, cuando no tuviesen enmienda, en cuya conformidad no dudo que se facilitaría la más pronta y mejor administración de justicia al paso que tales ejemplares serian de escarmiento a los reos, igualmente que de contención y comedimiento a los demás bogas para no reiterar las pagas y fugas continuadas, como ni tampoco multar con desvergüenza y amenaza a los mercaderes y pasajeros que conducen. y este mi sentir lo expongo por el conocimiento y experiencia que me asiste del carácter de los bogas, y de ser cierto cuanto se indica contra estos por la representación del señor procurador, y cuanto lleva referido lo certifico en la más bastante forma para que obre los más prontos y favorables efectos a que se dirige. Mompox once de febrero de mil ochocientos cinco, Pedro Martínez de Pinillos.

\section{Certificación}

Don José Martínez Troncoso regidor perpetuo del muy ilustre cabildo de esta villa, en ella y sus términos juez subdelegado de bienes de difuntos etcétera certifico que cuanto expone el señor procurador sindico general en el pedimento con que inicia estas diligencias, es puntualmente lo que acontece en el día con los bogas del rio Grande de la Magdalena, y demás navegables de este Reino; llegando a tal extremo de relajación e insolencia que no solo 
reciben a un mismo tiempo dos, tres, y más pagas bajo de distintos nombres y apellidos, sino que también cometen [folio 720v.] varios robos en las propias embarcaciones que conducen, rompiendo y abriendo los fardos y cajones del cargamento que exportan como experimento el exponente en nueve de febrero del año pasado de ochocientos tres en el champan nombrado la Santísima Trinidad que navegaba desde Cartagena al puerto de Nare y un boga de su misma tripulación llamado Santana Ribera tuvo el arrojo de romper dos fardos y robarse varias piezas de ropa de las que contenían y aunque fue preso in fraganti, y confesó su delito no se le aplicó otra pena que los de unos cortos días de cárcel; por que las justicias temen imponerles la que en semejantes casos corresponde sin que preceda seguimiento formal de causa: y como esto seria y proceder infinito por las dilaciones que ofrecen todos sus trámites, las partes agraviadas se retraen de sus querellas; los delitos quedan impunes y los delincuentes insolentados para cometer otros mayores. los bogas no respetan, ni tienen la menor subordinación a los pilotos pero ni tampoco a los mercaderes, y pasajeros que conducen sean de la clase que fueren, y por lo que son muy frecuentes las ocasiones que no solo atropellan y halan de palabras a unos y otros, sino que han hecho arma contra todos; y sin embargo de ser esto perjudicial y muy [folio $721 r$.] frecuente, no se cuenta un ejemplar de castigo correspondiente a tales desordenes sus bogas sin más motivo que el que les sugiere su natural perversidad abandonan la embarcación en cualquier paraje del rio aunque sea el más desierto y en el de mayor peligro; de que han resultado las perdidas y averías de los cargamentos que conducen sin que jamás se les haya dado la menor corrección por este delito tan perjudicial al interés común del estado. y últimamente los bogas es una clase de gentes que nace, y se alimenta con los vicios más torpes que carece de todo principio racional, y de educación Christiana y que no reconocen la menor subordinación a las justicias ni a las leyes; ya porque para los delitos encerrados, no se ha establecido aún ninguna penal que no sea capaz de contenerlos; y ya porque en la mayor parte son hombres vagantes de unos a otros pueblos sin domicilio ni lugar conocido estos desordenes y otros muchos que omito, crecen y se aumentan cada día y llegará a términos que se hará intransitable la navegación de este famoso canal que la divina providencia ha destinado para la mayor felicidad de los habitadores de este Nuevo Reino, sino se acude en tiempo a su remedio. todos los cuerpos más bien organizados además de las leyes generales de sus respectivos reinos y provincias, tienen sus particulares ordenanzas de leyes penales [folio 721v.] para su mejor gobierno y mantener en subordinación y obediencia a sus [individuos en beneficio común, y del estado así es que admiramos los tan sabiamente establecidos para los cuerpos de ejército y marina en donde por este medio resplandece el mejor orden de subordinación en todos los puntos de su instituto no es de menos consideración el cuerpo de bogadores que tiene este Reino para que no merezca de sus tribunales superiores el que se dignen dispensarle toda la que demanda la urgente necesidad de establecer, como en aquellos, una ordenanza penal adecuada a la clase y costumbre relajadas de las gentes que se compone; y circunstancias locales de la navegación interior del reino tanto a la de estos ríos de la Magdalena, como al de Cauca, y a todos 
los demás navegables; únicos canales por donde forzosamente circulan todos los intereses del real erario y particulares: punto a la verdad de los más importantes, y digno de la atención superior del más ilustrado gobierno de que disfrutamos pero como mientras se forma y establece dicha ordenanza, se haga indispensable contener provisionalmente el que los desórdenes expresados no tomen cuerpo ni que se haga más difícil su reforma, como es de creerse si se dilata la contención; parece muy conforme a equidad y justicia se adopte el medo propuesto por el señor regidor jubilado Don Pedro Martínez de Pinillos, en su antecedente certificada [folio722r.] exposición de que se le apliquen veinte y cinco azores en la reja de la cárcel a cada boga que cometa los delitos que quedan expresados con solo la inquisición verbal y cualificada del hecho, autorizada por el escribano para su constancia en todo tiempo. Mompox febrero veinte y uno de mil ochocientos cinco José Martínez Troncoso

Certificación

Don Ramón del Corral y Castro sargento mayor y comandante creado por $\mathrm{Su}$ Majestad (que Dios guarde) certifico: que consultada la experiencia de más de treinta años que me ofrece el manejo de los bogas de esta carrera del rio Grande de la Magdalena, al paso que no dejo de conocer y confesar hay muchos altaneros e insubordinados que por lo común son forasteros; también hay otros que sin ser los menos se manejan con un porte más regular en su clase: y que si de los primeros no hay duda se han advertido algunas atroces delincuencias tales como la de atreverse a tomar armas contra su piloto, contra el mercader y contra sus compañeros; exigirles pagas a los habilitadores adoptando diversos nombres, huir el cuerpo a la fatiga, profugando al tiempo de emprenderla, presentarse con severidad a ella, y luego desertarla a pocos pasos de su marcha, hasta atentar a la apertura de tercios que se conducen en las embarcaciones de los segundos, sin hacer agravio a la justicia no puede decirse con tanta generalidad sino es en aquella parte del mal ejemplo que reciben y que todo conspira a persuadir emanar inmediatamente de la falta de corrección y castigo proporcionado a su delito. el certificante tiene penetrado en bastante manera que con la sola cláusula que acaba de estampar tenia conclusa y llena la intención loable que se propuso el señor procurador general cuando se dedicó [folio 722v.] a instruir el presente expediente. pero como siempre ha prevalecido a su juicio el consejo que en todas edades ha difundido la sana política, de que importa más a la república escudriñar los medios de atajar el mal para que no se acerque, ni cunda a los ciudadanos que una vez introducido aplican canterios para cortarle: también ha creído oportuno y muy de su obligación que cuando se trata de indagar las penas capaces de contener un desorden como el que experimenta la navegación no menos se ocurra a aquellos medios suaves que pueden facilitarla o que no logrado vendría a hacer más odioso el procedimiento de la tripulación. es pues: que siendo notorio el aumento de la población por los mayores creces que ha recibido su comercio, los víveres a proporción han tomado un valor extraordinario en términos que si antes podía mantenerse un hombre diariamente con solo un real y una familia con tres; ahora no puede hacerse con dos, ni seis por exceder la diferencia de aquellos de más de un cuento por 
ciento y que siendo la regla igual a proporción respecto de las casas y bohíos, es ninguna la alteración que acerca de la antigua dotación y precio de sus viajes han venido a reportar las infelices personas dedicadas a llevar sobre sus hombros con el auxilio de una palanca al pecho el peso insoportable de un bote a champán colmado de cargas: para los solteros y que no tienen padres ni hermanos de que cuidan, cuyas obligaciones van siempre consigo pudieran muy bien cohonestarse los diez, y [folio 723r.] catorce pesos que se les satisface por su embarque y ocupación en estos buques, mas nunca dejara de ser una cohonestación poco menos que abusiva y de reato atendidas aquellas menudas consideraciones que quedan emanadas y en que todavía no entra la carestía de ropas necesarias a su vestuario aunque tosco y rudo. cuanta pues por este cálculo vendrá a ser dese luego la desgraciada suerte que prueban aquellos otros que por casados se ven rodeados de mujer e hijos y cuyas desnudez no exigen solo una muda para cubrir sus carnes como sucede con los primeros. estamos ya en que para los que no se detienen en una combinación semejante; la más mínima de estas reflexiones que no son de perderse de vista por su peso llegará tal vez a graduarlas por una condescendencia punible. Pero así como en Mompox no podrá darse ninguno, que en su caudal haya recibido mayor quebranto por los reprobados manejos de los bogas, cuyas sumas que me adeudan sobrepasan a más de cuatro mil pesos; tampoco habrá quien me exceda con el discernimiento que he hecho siempre de estos, atribuyéndolos a unos principios de necesidad y de miseria, viendo que reanimándose todos los ramos de industria y artes en la villa solo la de ellos prevalece en el mismo grosero pie que heredaron de sus pasados. remitámonos a la prueba y ella decidirá la cuestión. contribúyase a cada hombre de champan catorce pesos y a los de botes diez y seis, a los pilotos de aquellos diez y ocho y a los de estos veinte por viaje y ente sin perjuicio del viniente satisfaciéndoles [folio 723v.] siete pesos a la salida de esta villa, tres en Honda con los que y el viaje que ordinariamente tomará allí para abajo se socorren muy bien comprando algo para traer a sus casas, y los cuatro restantes al retorno facilitándoles el medio de mantenerse con su familia ínterin que toman nuevo viaje. practíquense lo mismo respecto de los de Barranca, Cartagena en tiempo de Dique y demás ríos por donde quiera que naveguen y se haga como con consideración a las distancias; y este aumento agréguese a los cargadores que no harán más que suplirlo porque a la venta de sus mercaderías lo exigen de los consumidores. y he aquí un recurso de cortar la deserción y suposición de enfermedades, porque la seguridad con que van a tomar en Honda los tres pesos además de su pagamento para abajo y después aquí los cuatro les alienta a rendir enteramente con honradez su viaje, y si entonces no obstante la proporción que se les brinda y con que se estiman compensadas sus fatigas y acerbo trabajo se observase que el mal pasa adelante, podrán decirse justificadas con doble razón las penas a cuya declaración con la más urgente necesidad se conspira, como que por lo mismo no es mi ánimo tampoco dejen de impetrarse a prevención con tal de que obtenidas por el señor procurador general, no solo se preceda la circunstancia de que se publiquen por bando para que lleguen a la noticia de todos, sino que al tiempo de su paga se les haga capaz de ellas a cada uno en [folio $724 r$.] 
particular a fin de que no aleguen de ignorancia ni el juez tampoco tenga motivo de indulgenciarles, sino antes bien de proceder sin respeto con el rigor que corresponda. Mompox abril seis de mil ochocientos cinco.

Ramón del Corral y Castro

Certificación.

Don Manuel de Herrara y Berrío administrador principal de las reales rentas de tabacos y pólvora del departamento de esta villa por Su Magestad certifico a consecuencia del antecedente pedimento del señor procurador general don Francisco Bárcena Posada y proveído del señor alcalde ordinario don Melchor Sáenz Ortiz más para poderlo hacer de modo que obre los efectos que se propone el expresado señor procurador general formaré una descripción del carácter y cualidades de los bogas del río de la magdalena. estos hombres se crían del modo más bárbaro y lastimero. antes de despertar en ellos el uso de la razón los padres los destinan al mismo ejercicio de bogas, haciéndoles hacer al principio jornadas proporcionadas a sus fuerzas, hasta que se ponen en estado de mayores empresas. dedicados ya a este ejercicio no tienen lugar de aprender la doctrina Christiana ni aun superficialmente los padres también la ignoran y así no pueden enseñarla a los hijos por consiguiente no saben lo que es religión, urbanidad, ni moderación su trato entre ellos mismos jamás les puede producir algunas ventajas. la libertad de su crianza, y los ejemplos de los demás que no pueden ser sino los peores los enseña a obrar del mismo modo sin que haya quien las corrija ni haga arreglar sus costumbres. cuando han llegado a la edad de veinte años los principales vicios están radicados en ellos, y [folio 725r.] especialmente el de la embriagues en lo que consumen cuánto adquieren legítima o legítimamente se burlan y miran con desprecio a los jueces de los lugares por qué tienen el fácil arbitrio de pasar de uno a otro después de cometer cualquier delito, por qué en los mismos compañeros hallan para esto los auxilios necesarios, y si se aparecen en el lugar donde se trató castigarlos, es bajo de toda precaución y cuando consideran, que el transcurso de algún tiempo y otros asuntos lo ha hecho olvidar, de cuyo modo queda impune, por otra parte ( como se dice en los anteriores certificados ) de oficio no -pueden proceder los tres. jueces, y los interesados no solo tendrían que gastar algún dinero en la formación del expediente para probarles el delito seria que invertirían el tiempo que necesitan para asuntos más importantes, y estos perjuicios los hace retraer o abandonar cualquier intento o queja. esto supuesto ¿que no debe esperarse de unos hombres sin educación, sin conductas, sin religión, y sin subordinación? forzosamente todos los males que se hallan especificados en los antecedentes certificados principalmente el del doloso arbitrio de percibir pagar dobles bajo de distintos nombres, y el de profugar abandonando la embarcación antes de llegar a su destino. de cuyo motivo es que se ha perjudicado las rentas de mi cargo en varias cantidades, sin arbitrio por mi parte mi dolo de recaudarlas, sino también de no poder evitar en los sucesivo la continuación de este quebranto, así como les sucede igualmente. a todos los demás de embarcaciones en [folio 725v.] tales circunstancias ¿quién no será capaz de conocer la necesidad de remedio para unos males positivos, y para precaver otros mayores que por la misericordia de dios hasta a hora no se han experimentado, pero con el tiempo, la 
proporción que brinda la carrera desierta y desamparada, y el incremento que va tomando la malicia, atrevimiento y audacia de estas gentes insubordinadas pueden cometer? todos los trámites del (universo), y aún el de las naciones más bárbara e incultas procuran mejorarlos cuánto se puede porque en esto consiste la felicidad de los lugares ninguno ignora esto y que el río de la magdalena es tránsito preciso para lo interior del reino de Sante Fe, Quito, Lima ¿cuántas rentas deberían lograr estos lugares en su comercio si se hubiera mejorado la carrera de todos los modos de que. es susceptible? pero es visto que desde la conquista de este reino hasta ahora casi nada se ha adelantado, ni aún lo menos difícil y costoso, y acaso lo más necesario que es el arreglo de un cuerpo de bogas desorganizados que se ha formado por los accidentales accesos. Así pues, el pensamiento del señor procurador general es laudable y por lo mismo debe esperarse de la superioridad que competa las providencias más prudentes y acertadas para remedio de tales males, bien del público, y del comercio en que se interesa tanto la Monarquía. Mompox abril veinte y siete De mil ochocientos cinco. Manuel de Herrera.

Certificación

Don Joaquín Lascano. Regidor, depositario general Jubilado y administrador general de las rentas de [folio 726r.] Aguardientes y naipes de esta villa y su departamento por el Rey Nuestro Señor, vuestro certifico con vista de lo pedido por el señor procurador sindicado general Don Francisco de la Bárcena Posada; decreto del señor alcalde ordinario de primera numeración Don Melchor Sáenz Ortiz, e informes dados por los secretarios Don Pedro Martínez de Pinillos, Don José Antonio Troncoso, Don Ramón del Corral y Castro, y don Manuel de Herrera que antecedan que siendo notorio cuánto dichos señores exponen sobre los criminales abusos, con que comportan los bogas en el manejo de su ejercicio con conocido perjuicio al público, comercio, y a las hacienda, no puedo menos que reiterar sus contenidos; pues la practica experiencia que tengo adquirida muchos años (hace) con el motivo de haber obtenido los empleos de contador principal de las reales rutas de aguardientes y tabacos en la villa de Honda, y el actual empleo de administrador y las continuas quejas que no solo los mercaderes tramitantes, sino aún también los superiores y demás empleados que han subido al Reino, han manifestado a su arribo en Honda por la malversación de dichos bogas en la navegación, ya recibiendo soldadas de varios individuos, burlando a todos al tiempo del embarque, ya haciendo fuga en medio del tránsito, y ya finalmente demorándose en cualesquiera lugar los días que quieran con detrimento de los intereses y personas que conducen me hace decir urgentísimo poner el conveniente remedio, consiguiéndose una superior declaratoria, que sea capaz (por [folio 726v.] la pena que se impongan) de contener tan pernicioso desorden que es a lo que aspira el celo del señor, procurador general con lo que lograrán ser beneficiados aun los mismos bogas, porque temerosos de que no se les apliquen procedencia con juiciocidad a desempeñar su obligación sin dar lugar a cargarse de pagar con detrimento de sus familias, y el comercio libre de estas estafas. Mompox mayo dos de mil ochocientos cinco. Joaquín Lascarro. Testado. Antonio de los Santos Muñoz. No vale. 
Concuerda con los originales que para. efectos de esta compulsa me puso de manifiesto el señor procurador jurídico general Don Francisco de la Bárcena Posada, a cuyo poder Me remito. Mompox once de mayo de mil ochocientos cinco. Carlos José de Ledesma

De oficio

[folio 729r.] Con presentación de documentos solicita la providencia que expresa.

Excelentísimo Señor

José de Vargas apoderado del síndico procurador General de la villa de Santa Cruz de Mompox, en virtud de su poder que tengo presentado en esta superioridad, en el expediente sobre el remate del oficio del regidor decano de la misma, ante vuestra excelencia en la vía y forma que más haya lugar en derecho con mi acostumbrado respeto parezco y digo: que mi constituyente estimulado de los deberes de su propio ministro y de un heroico patriotismo, con el interesantísimo objeto de que se ponga término a los continuados desastres, robos, y criminales incidencias que diario e impunemente ejecutan los bogas de aquel tránsito, y demás puertos situados a orillas del río de la Magdalena en odio de las particulares dueños de los buques, de los traficantes, de la causa común del Real Erario, y de todo el comercio, solicito ante al alcalde ordinario de primer voto de la referida villa la respectiva justificación que en testimonio con la solemnidad, y juramento de estilo en diez fojas útiles acompaño.

De ella pues resulta por las constantes, e uniformes aserciones del alcalde Mayor provincial Don Pedro Martínez Pinillos, del regidor su decano y juez subdelegado de bienes de difuntos Don José Antonio Troncoso, del sargento mayor del cuerpo de cazadores de milicias urbanas Don [folio 729v.] Ramón del Corral y Castro, y de los administradores principales de las reales rutas de tabacos, y aguardientes Don Manuel de Herrera, Don Joaquin Lascano que ha llegado a tal extremo el abandono y prostitución de los bogas de aquel tránsito o vereda, que con el punible arbitrio de darse diversos nombres encubriendo los suyos propios cuando se hacen las habilitaciones de los champanes, aun mismo tiempo, se comprometen a distintos viajes, recibiendo con anticipación de todos los interesados las correspondientes pagas: que por lo común con ninguno cumplen, ya no compareciendo el día de la salida, o ya profugandose a principios de la navegación con el apocado designio de restituirse a aquella villa a reiterar sus engaños para fomentar sus vicios, licenciosas y corrompidas costumbres; que este lamentable desorden, y cuasi universal trastorno no trae otro principio, ni origen que la falta de condigno castigo y corrección; pues exigiéndose para. su imposición una rigurosa sustanciación. por los términos ordinarios los jueces a qué se ocurre, o por no haber quien sufrague las costas, o por un efecto de piedad mal entendida se contentan con tener a los delincuentes unos cortos días en prisión que siendo estos una clase de hombres a quienes como amamantados en los vicios sin principios de religión, y destituidos de todo sentimiento de honor solo puede contener la severidad de un pronto castigo; para cuya falta, y satisfechos de su propia impunidad, que les aseguran los continuados, y repetidos ejemplares 
en, vez de tener alguna enmienda, antes se obstinan, y prostituyen a mayores excesos; y que. con la misma facilidad, y desenfreno ofenden, ultrajan e irrespetan con dicterios, y atrevidas amenazas a los pasajeros o traficantes $\mathrm{Su}$ Excelentísimo señor así lo certifican [folio 730r.] cinco fidedignos e importantes sujetos de los principales y más condecorados de aquella villa, adoptando unos por temperamento o único arbitrio para contener tan lamentables desordenes el aumento del precio o salario de los mismos bogas, otros la severidad del castigo, pero todas convienen que este se ejecute con solo la constancia del delito sin necesidad de observar los rigorosos, y dilatados trámites de una sustanciación ordinaria, fundados ya se ve, en lo que les ha hecho palpar una prolongada experiencia, en la condición bárbara, y grosera de semejante clase de gentes a quienes solo la eficacia, y prontitud de un severo castigo, les puede enderezar a los justo y arreglado.

Todo así lo conocen, como también que de retener dilatado tiempo a los bogas en prisión en vez de resultar alguna ventaja o enmienda, antes se priva la republica de su servicio, y de ellos sin algunos jornales, ni de donde subsistir caen en mayor miseria, que inmediatamente. que se ven libres solo tratan de remediarlas a costa de nuevos fraudes, robos, y engaños y he aquí el verdadero origen de que estos en día en día, y por momentos se vayan multiplicando en odio de la causa común, y con indecible detrimento de aquella república, y sus habitantes.

Es pues de esperarse de la recta justificación de Vuestra Excelencia que cómo tan interesante en la felicidad de los pueblos en la prosperidad del comercio, y en la corrección de los crímenes, se sirva por un efecto de sus elevadas facultades dictar por pronta providencia que al boga que aun mismo tiempo se compromete a diversos viajes recibiendo las respectivas pagas que no sale al día pactado, que después de emprendida la navegación [folios 730v.] la abandona, o que irrespetan o maltrata a los sujetos que conduce, con solo la constancia y notoriedad de su delito, sin necesidad de otra sustanciación se le castigue y escarmiento prontamente conforme a su naturaleza y gravedad, diputando a uno de los sujetos, o jueces de aquella villa para que privativamente conozca de semejantes causas, para que con motivo de otras no difiera su pronta evacuación como hasta la presente ha sucedido, según lo acreditan los mismos documentos que dejo presentados. todo en el interés se toman otras medidas y medios que sirvan de regla en el particular que todo parece conforme y de justicia que medianamente con el pedimento más útil a Vuestra Excelencia suplico provea y mande que en lo necesario

Licenciado. Emigdio Benítez José de Vargas

Santa Fe julio 15 de 1805

Por presentarse con los documentos al señor fiscal.

Caicedo.

Excelentísimo Señor

El fiscal de lo civil dice que en este mismo documento [folio 731r.] están pendiente las diligencias mandadas practicar en decreto al 9 de enero de 1805: y para que se ejecute lo que se ha considerado necesario se ha de servir Vuestra Excelencia mandar se pidan librándose orden como es de fuerza. Santa Fe julio 19 de 1805. 
Santa Fe, julio 21 de 1805

Vistos: por ahora se guarde lo mandado en veinte y dos de septiembre [folio 731v.] de mil setecientos ochenta y ocho, cuya provincia se sobrecartara con declaración que al boga que se comprometiere a diferentes viajes incompatibles en tiempos, recibiendo más de una paga, al que no saliese en el día pactado, o que emprendida la navegación, la abandonase, y al que irrespetase o maltratare a los sujetos que conduce, se le deberá castigar con la constancia del suceso por notoriedad o justificación sumaria en que resulte confeso, siempre que la pena no exceda de un mes de prisión o trabajo de obras públicas en el distrito del cabildo respectivo, además de la restitución de la cantidad que indebidamente hubiere percibido. y para lo demás que corresponda moverse se esperen los resultados de la providencia al nueve de enero de este año, librándose ordinario para su pronta remisión. enmendado [folio 732r.] catorce de agosto de este año pase noticia del antecedente apartado ante el señor Diego Frías fiscal de lo civil su (visa) doy fe Martínez En dieciséis de dicho mes hice citar a José de Vargas apoderado del síndico procurador general de la villa de Mompox. Doy fe Vargas Martínez.

Traído el 21del mes

Esto 23 de este mes se libró despacho por el próximo correo 29 del mayo del 1807, se dirige orden a las Justicia de Mompox, para la pronta remisión de la resueltos de la superior providencia que enuncia la anterior foja 1.

[folio 733r.]

Don Antonio Amar y Borbón Arosieda y Vallejo de la Santa Cruz. caballero profeso de la orden de Santiago, Teniente general de los reales ejércitos, Virrey gobernador, y capitán general del nuevo Reino de Granada, Presidente de la Audiencia y Cancillería Real de Santa Fe de Bogotá, superior Intendente General de la Real Hacienda y reales rentas estancadas subdelegada de la del correo en el distrito del virreinato hago saber a las justicias ordinarias de la villa de Mompox que en este superior gobierno y superintendencia general, penden auto promovidos por los diputados del comercio de esta capital, a nombre de todos sus individuos, y de otros interesados sobre los perjuicios que experimentan en la condición o transportación de géneros de las provincias, de Cartagena, y Santa Marta que se embarcaran en el río Magdalena y en cuyo particular por el año mil setecientos noventa y dos, les libro superior despacho, a efecto de que los dueños de embarcaciones de aquella villa, y su jurisdicción, expusiesen los conveniente en cuanto a los puntos expuestos por los diputados practicados en su cumplimiento las correlativas diligencias y dándose cuenta con ellas, se corrió traslado que se evacuó en los términos siguientes Excelentísimo Señor. los diputados del comercio de esta capital contestando a las diligencias [folio 733v.] practicadas con los dueños de los champanes y botes, por Don Pablo José Torregrosa, y los alcaldes de Mompox, el Marqués de Torre Hoyos, y Don Felipe Sánchez de Mavellan impuestos de los que ellas resultan, los hallamos conformes a la pretencioso de nuestros antecesores, menos en aquella parte en que se les hace cargo de responsabilidad a los citados dueños de las canoas, quienes como interesados, dicen que no les son exequibles, y aún con todo convienen a la quinta regla, o proporción de pagar las asignación al juez de bogas siempre 
que salgan fletado por un tanto, que a fojas treinta y nueve vuelta dicen es corriente y los mismo es si los cascos solo se alquilasen por qué llevaran al respecto de los bogas que ocupe el buque: de suerte que siempre quien paga al dicho juez es el comercio, y los pasajeros, y no los dueños de los cascos, a la séptima, exponen no les es adaptable porque no les reportan las ventaja correspondientes, y esto es por libertarse de todo reato pues lo que pretende el comercio es que si faltase algún tercio, cajón, botijas de vino, y muchas empezadas sin padecer naufragio inculpable, sea de cuenta del dueño de las canoas para que así con especial cuidado ponga un piloto, y boga de buena conducta, los que no faltan según dicen a foja a cuarenta y seis, y para mayor seguridad pondrán puertas de quitar y poner en las boca toldas de los champanes (que los botes la tienen) con sus llaves que guardará el piloto y las cerrará, o abrirá cuando sea necesario para registrar si hace agua el casco, o cae alguna gotera en lo que ha de poner el mayor cuidado [folio 734r.] y lo mismo en las piezas que recibe, lo que puede y debe hacer sin tropelía ni aceleración; sino es con la formalidad que pide el caso. De todo lo dicho se advierte la responsabilidad que pide el comercio a los dueños de las embarcaciones, y no la de incendio y naufragio inculpables, sin que ignoremos que en Cartagena hay caso de seguro, y aunque viniera asegurado siempre la avería por defecto del casco, la pagaría el dueño del barco como sucede con las que vienen de España a los puertos de América también será de cuenta de los dueños de las embarcaciones cualesquiera avería que se padezca por no poner las corrientes, y muchas ocasiones llega a tanto extremo de indiscreto celo de los canoeros que un champán acabado de bajar de Honda lo mandan de Barranca sin tocar la tolda ni repasar las juntas, o echarle algún rumbo o pieza dejándolo de un viaje para otro, por no gastar el vil y bajo interés de doce pesos. Y con esta indolencia conducen treinta a cuarenta mil pesos de géneros en unos barcos que muchos debían estar quemados sobre lo cual ha de poner el mayor cuidado el juez sobre que se pague el flete por el mercader en Mompox, o en Honda parece extemporánea la proposición hecha por los canoeros de Mompox, a fojas cuarenta y dos y la de Don Manuel José Valles trae en foja veintisiete vuelta por cuanto es contrato por separado entre el comerciante y los dueños de los cascos, y al que no sea abonado buen cuidado tendrán de no darle su embarcación al fiado, sin abonar la conducta de los bogas. Muchas veces [folio 734v.] tienen la culpa de sus deserciones los dueños de las embarcaciones porque les dan poca y mala carne con mucho hueso, y diez pesos en plata al piloto para comprar plátanos en la manutención de veinticuatro hombres en veinticuatro días (que es el ordinario que tarda un champan de Mompox a Honda) y si por estar crecido el rio u otro acaecimiento tardan más tiempo, se ven obligados a robar sobre lo que el citado juez debe vigilar para quitar de toda disculpa al boga y lo mismo en que la embarcación salga bien pertrechada de bocas toldas, fogas, cabrestillos, estopa, martillos y escoplo que todo puede importar ocho pesos, que por no gastarlo se arriesgase muchos miles, y muy rara la vez que ponen lo dicho, y más rara la embarcación que a los pocos días de navegación no hace agua y con todo lo dicho se ha de provenir que salgan todas las embarcaciones, aun cuando el mercader, o pasajero no lo pidan, porque es bien notorio que de 
cuantos suben al rio la primera vez, ninguno sabe lo que es necesario, y si alguno lo advierten, es a fuerza de mendigar, y adquirir noticia todo lo cual se remedia con que al salir la embarcación del puerto la registre el juez, sin cuya licencia no podrá salir y lo mismo sino lleva los bogas correspondientes a la carga en cuanto a que los bogas disiparían sus alcances si se les pagase la mitad en Mompox y lo demás en Honda según dicen a fojas cuarenta y una vuelta no ignoran los dueños de las embarcaciones que antes de salir de Mompox gastan hasta el último medio real, y solo salen con alguna camisa o calzón, que si les ha costado dos pesos, lo venden en el rio [folio 735r.] por la mitad, o menos y como ya no tienen que esperar en Honda después de gastado el dinero se resfrían en tanto extremo al trabajo que les da lugar a huirse, lo que no hicieran con tanta facilidad sabiendo que la mitad de la soldada la habían de recibir en Honda, donde empleados en frutos del Reino, y llevado a Mompox les reporta mucha utilidad y lo que ahora sucede es que inmediatamente que un champan, o bote llega a Honda despiden todos los bogas, quedando solo el piloto y otro para la custodia, y los demás infelices sin tener donde buscar medio real se van en cuatro palos rio abajo y a la primera casa, o estancia que encuentran, dicho se está que llevados de la necesidad, irán a robar, y los que gastaran mal su dinero recibiéndolo en Honda serán los de mala conducta, pero no los de buena que ha foja cuarenta y seis dicen no faltan y a estos se les quita este recurso. Nos parece regalar, y bastante, que cada champan, o canoa pague un real de cada boga que ocupe y el bote a dos reales que pagarán los dueños y estos tendrán buen cuidado de sacarlo en el flete como ya se ha dicho y aun cuando a su comerciante le salga cuatro reales más cara que ahora la carga de efectos que vale de cuatrocientos a mil pesos, lo dará por bien empleados viniendo como corresponde por todo lo cual y reproduciendo cuanto tienen dicho nuestros antecesores a Vuestra Excelencia pedimos y suplicamos se sirva mandar que con el mayor empeño, y tesón, se lleve todo a puro y debido efecto imponiendo las rigurosas penas que juzgue necesaria su justificación, con lo demás que tenga por convenientes para la perfección de tan importante navegación, como útil a todo el reino Excelentísimo Señor Lorenzo Marroquín de la Sierra - Bernarda Gutiérrez. Excelentísimo [folio 735v.] Señor Don José Espeleta Virrey Gobernador, y Capitán General - con motivo de cierta queja dada por Don Alejandro Pozo del vecindario de Honda sobre la conducta y procedimientos de un boga, Manuel Campos, se pasaron los autos al señor fiscal quien expuso sin visita, cuyo tenor, y el del decreto que con acuerdo del Doctor Don José Ignacio San Miguel abogado de esta Real Audiencia por indisposición del señor asesor general del virreinato tuve a bien proveer dicen así.

Vista fiscal

Excelentísimo Señor. El fiscal de lo civil dice: que el asunto pendiente desde el año de noventa y dos consiste en establecer reglas de seguridad a el comercio de esta capital, y evitar robos, y fraudes en los botes que conducen los tercios, y cargas de comercio originado de la mala conducta de los pilotos y bogas que los que los conducen. Los dueños de ellos, se allanaron a los que propusieron los diputados en representación de nueve de junio de setecientos noventa y uno, excepto con las que los constituye en responsabilidad, que ya 
resistido que son la séptima, y que cita Don Ramón del Corral en la notificación de doce de marzo del citado año de noventa y dos. Don Domingo López, pidió el expediente para exponer por su parte lo que correspondía a su derecho. Los diputados en la representación que dio motivo a la respuesta que [folio 736r.] ahora da explican sus capitulaciones, y sentido de ella, pero como no se puede constituir a los dueños de botes en obligación alguna, y que no están prevenidos de lo que desea este comercio, podrá Vuestra Excelencia si fuere servido emplazarlos, para que contesten, y produzcan lo conveniente a sus particulares intereses. Y en que auto a el punto nuevamente pendiente, supuesto de que se han encontrado los cuadernos agregados podrá volver a el señor fiscal del crimen. Santa Fe enero cinco de mil ochocientos cinco. Frías Decreto

Santa Fe enero nueve de mil ochocientos cinco. A sus autos y vistos: como parece el señor fiscal. En el punto pendiente sobre el arreglo de la navegación por el rio de la Magdalena trasladado, y en caso necesario se librara el correspondiente emplazamiento cometido a las justicias de Mompox y en cuanto a la queja contra el boga Manuel Campo, con los cuadernos agregados pase a la vista del señor fiscal del crimen - hay una rúbrica San Miguel Rojas - en cuya virtud he acordado liberar como en efecto libro el presente y por el ordeno, y mando a las mencionadas justicias de la Villa de Mompox y que luego que lo reciban o, como en cualquier manera les sea entregado, procedan a notificar, y emplazar a los dueños de botes en esa villa, y su jurisdicción, ocurran a este superior gobierno dentro del término de la ordenanza por si, o por apoderado instruido, y expensado, a deducir lo que vieren convenirles en punto a la solicitud pendiente de que hace merito la representación inserta de los diputados de comercio de esta capital: con apercibimiento, que así no lo haciendo les parara el perjuicio que haya lugar. Para todo expido. Firmando de mi mano en Santa [folio 736v.] Fe a cuatro de febrero de mil ochocientos y cinco años.

Antonio Amar

por mandado de [justicia]

Domingo Caicedo

Vuestra Excelencia previene a las justicias ordinarias de la villa de Mompox emplacen a los dueños de los botes en ellas y su jurisdicción para que ocurran a contestar el traslado que se les ha conferido en la instancia que pende de los diputados de comercio de esta capital sobre los perjuicios que sufren en la navegación [folio 737r.] a efecto de que se notifique a los dueños de botes de esa villa, y su jurisdicción, ocurran a contestar el traslado que se les ha conferido en la instancia que pende de los diputados de comercio de esta capital sobre los perjuicios que sufren en la navegación: acompaño a Vuestra Merced el superior despacho del Excelentísimo Señor Virrey- Dios guarde a Vuestra Merced muchos años como deseo.

Santa Fe febrero 9, de 1805, Domingo Caicedo

Señores alcaldes ordinarios de Mompox [folio 739r.]

Mompox febrero 18, de 1805. 
Por recibido con el superior despacho del Excelentísimo Señor Virrey del Reino, su fecha cuatro del corriente se ubica en la forma ordinaria y en su cumplimiento hágase saber a todos los dueños de las embarcaciones, que en el superior decreto de nueve de enero último se expresa, ocurran a aquella superioridad en el término de la ordenanza, a usar de su derecho.

[firmas] Melchor Sáenz Ortiz Isidro Mendoza Carlos José de Ledezma En el mismo día di noticia del antecedente proveído al señor regidor decano, y juez subdelegado de bienes de difuntos Don José Martínez Troncoso, quien después de haberse impuesto de la inserta representación de los diputados de Santa fe, dijo: que el fletamento de embarcaciones según el artículo primero de la ordenanza que con real aprobación gobierna la marina mercantil, es propiamente un contrato que se hace entre el dueño del buque y la persona, $o$ personas que intentan cargar, y ocupan la embarcación de unos puertos a otros, bien sean de mar, o de rio, pagando aquel flete, o alquiler que voluntariamente hubiesen convenido, sin que el negociante, o [folio $739 v$. ] pasajeros pueden exigir del dueño, o consignatarios, ni estos de aquellos, más cantidad, ni seguridades que las que hubiesen capitulado antes de embarcar las mercaderías en los términos prevenidos en el artículo cuarto de la propia ordenanza. Esta misma, regla las obligaciones del capitán, piloto, maestre, y tripulación receptiva de cada buque. Y detalla las penas en que incurren por cualesquiera falta de subordinación, robo, u otro algún delito que cometan en la navegación, sin que los dueños de los buques sean responsables de cosa alguna solo en el caso de que voluntariamente se hayan obligados, y contratándolo libremente con el cargador, siendo bien notorio, que el buque solo es responsable de la avería de cubierta, y estos en sus casos, porque la avería menor, mayor, y abarrotería de patrón se asegura por separado a voluntad del negociante, pagando aquel interés que estipule con el asegurador, sin que tenga en ella la menor intervención el dueño del buque. Y por lo que respecta a los robos de la navegación son inmediatos responsables los maestres que reciben a bordo los cargamentos, y no los dueños de los buques en manera alguna.

Bajo de estos principios es que debe organizarse la navegación interior de este Reino, y no los medios que proponen, y solicitan los diputados de la capital, que parece no tienen conocimiento de ella; pues que utilidad resultara al comercio general con elegir jueces particulares de bogas establecer matrículas, y subyugar a los dueños de embarcaciones a que sean responsables de los cargamentos que conducen sus buques; si no la de imponer otras tantas trabas que entorpezcan, y aniquilen la navegación interior como medios positivos de dirigirlas a su destrucción con incalculables perjuicios del propio comercio, agricultura y del estado, a que por lo regular conspira la multiplicidad de jueces mayormente cuando el cuerpo que va a gobernar no tiene ordenanza penal, ni económica porque dirigirse parece pues más conforme a toda razón el que promoviesen la formación de una ordenanza penal que reglase el gremio de bogas análoga a su navegación, clase, y costumbres, cuyos conocimientos es fácil adquirirlos de los mismos pueblos de un naturaleza situados a las orillas del rio; cuyo medio sería el más 
conveniente para restablecer el buen orden en [folio 740r.] este cuerpo gremial de bogas que por la situación local de este reino merece la primera atención. Bajo de cuyos conocimientos, y de la costumbre observada en esta navegación desde la conquista, es, que el señor que expone extendió su comercio al ramo de embarcación que sostendrá mientras reporte utilidad y abandonara siempre que no le tenga cuenta el seguirlo por los desórdenes, y trabas que se le impongan, o que de ellos resulte algún prejuicio; no omitiendo manifestar que de los dueños de embarcaciones que enuncian los diputados de Santa Fe, solo existe con este giro Don Ramón del Corral, y que desde aquel tiempo al presente han variado las circunstancias que influyeron aquellas contestaciones. Esto expuso, y lo firmo para ente mi de que doy fe. [firmas]

José Martínez Troncoso. Ledesma

Seguidamente practiqué igual diligencia Doña Manuela Gutiérrez quien enterada de todo dijo: jamás, ha tenido, ni tiene botes, y si barquetones de varios tamaños con algunos pocos buques mayores de la carrera de Honda, y otros destinos para donde los fletan los sujetos que los necesitan, y en estos casos proceden con ciencia ocular buscando a su contentamiento y pagando al piloto y bogas que han de conducir su persona, y mercaderías, militando la misma razón cuando se manejan por apoderado las tales remeras, y conducción, y que sobre lo más que se ha representado, y reproduce la exposición del señor regidor Don José Martínez Troncoso, y lo firma

[firmas]

Manuela Gutiérrez. Ledezma

Señor Alcalde Ordinario

El escribano suspenso, quien entrega este expediente en virtud de lo mandado en decreto de esta fecha, hace presente que la demora que se manifiesta en el curso de él ha dependido de habérsele traspapelado con el motivo [folio 740v.] de haber mudado el archivo después la revolución de él, a causa de la amortización para dar la cuenta que sobre el particular se le previno sin que haya intervenido malicia, ni otra fealdad en el asunto por lo que lo hace presente en obsequio de ignorancia. Mompox doce de junio de mil ochocientos siete.

[firmas]

Carlos José de Ledezma. [folio 741r.]

Jueces de Mompox

Santa Fe julio veintisiete de mil ochocientos cinco visto por ahora le guarde lo mandado en veintidos de septiembre de mil setecientos ochenta y ocho, cuya providencia se sobre acatará con declaración, que al boga que le comprometiere a diferente viajes el incompatible en tiempo recibiendo más de una paga, al que no saliere en el día pactado o que emprendida la navegación la abandonare, y al que irrespetare o maltratare a los sujetos que conduce, se le deberá castigar con la constancia del suceso por notoriedad, o justificación sumaria en que resulte confeso, siempre que la pena no exceda de un mes de prisión, o de trabajo de obras públicas en el distrito del Cabildo respectivo, además de la restitución de la cantidad que indebidamente hubiere percibido. Y para lo demás que corresponda proveerse, se esperen los 
resultados de la providencia de nueve de enero de este año, librándose orden para su pronta remisión. Hay dos rubricas, Caicedo.

Esta copia lo es del superior decreto original [folio 741v.] que dictado le haya a consecuencia de lo representado por el procurador general de Mompox, solicitando providencia para contención y castigo de las iniquidades que cometen los bogas cuando le hacen las habilitaciones de los champanes a que me remito. Santa Fe mayo veinte y trece mil ochocientos siete años.

[firmas]

Ramón Bustamante

[firma ilegible]

[folio 742r.]

Acerca de lo representado por el procurador general de esta villa en cuanto a las iniquidades que cometen los bogas cuando se hacen las habilitaciones de los champanes [ilegible] se ha dignado el Excelentísimo Señor Virrey proveer el superior decreto que acompaño a vuestra merced para su cumplimiento en el punto de la pronta remisión de diligencias del emplazamiento librado en 9 de enero de 805, cuyo superior despacho giro a Vuestra Merced por el correo 9, de febrero del mismo Dios guarde a Vuestra Merced muchos años.

Santa Fe mayo 29, de 1807

[firmas]

Ramón Bustamante

Señores jueces de Mompox.

[folio 744r.]

Mompox 8 de junio de 1807

Por recibido con la copia de la superior providencia que cita: se obedece en la forma ordinaria y para tratar de su cumplimiento con citación del señor procurador general póngase con los antecedentes y tráiganse.

Pantaleón Germán Ribon, Nicolás Valest, Antonio de los Santos Muñoz

En ocho del dicho se notificó el proveído antecedente al señor procurador general Don Gerónimo Escoreca quedó impuesto doy fe

Escoreca

Muñoz

[folio 744v.]

Mompox junio 12 de 1807

Vistos: Resultando que en cumplimiento de la superior providencia que se tiene obedecida por el presente juzgado se dispuso y verificó su publicación por bando en la forma ordenada desde nueve de octubre del año pasado de mil ochocientos cinco, y echándose menos la superior providencia de nueve de enero del mismo año que se asegura haberse remitido en nueve del siguiente febrero cuyos reenvíos se esperan por la superioridad para lo demás que corresponda proveerse en el asunto de que tratan las citadas providencias la escribanía informe en el día de que esta falta a reserva de proveerse en su vista lo que se juzgue de justicia y entiéndase con citación del ministerio sindico Pantaleón Germán Ribón Nicolás Valet. Antonio de los Santos Muñoz.

Se notificó el proveído antecedente al señor Procurador síndico general Don Gerónimo ErcoReca. Ercoreca - Muñoz 
[folio 745r.]

Dicho día, se notificó al escribano de cabildo Don Carlos José de Ledezma, como en cuya oficina debían existir los antecedentes que se han echado menos, en su consecuencia hizo exhibieron de ello y firma doy fe.

Ledezma.

Mompox agosto 18 de 1807 Reconociéndose de esos autos que la superior providencia nueve de enero de mil ochocientos cinco, ha sido intimada solo al señor regidor Don José Martínez Troncoso y Doña Manuela Gutiérrez y existiendo otros dueños de champanes y buques del rio, como lo son Don Francisco de la Bárcena Posada, Don Melchor Sáenz Ortiz, Don Justo Piñeiro, y el señor Sargento mayor Don Ramón del Corral y Castro, extiéndase con ellos igual diligencia, y con lo que resulte [folio $745 v$.] quedando testimonio del expediente Diríjase original al Excelentísimo Señor Virrey del Reino, en cuya superioridad le espera para la providencia que corresponda de justicia

Ribon - Valest

Ledezma

Seguidamente notifiqué el decreto antecedente al señor sargento mayor del cuerpo de cazadores urbanos Don Ramón del Corral y Castro quien impuesto de su contenido dijo: Que quedaba impuesto de la representación hecha por Don Lorenzo Marroquín de la Sierra y don Bernardo Gutiérrez como diputado del comercio de Santa Fe comprehendida en el superior despacho mandado librar por el Excelentísimo Señor Virrey del Reino en cinco de enero de mil ochocientos cinco, y en efecto expedido, en cuatro de febrero del propio año que también lo queda del superior decreto librado el veinte y siete de julio del presente que en copia autorizada el veinte y tres de mayo último, fue dirigido con el correspondiente oficio de la escribanía a Su Majestad los señores alcaldes ordinarios de esta villa que mucho pudiera exponer en opósito de la pretensión infundada de dichos diputados en querer sujetar los dueños de los buques en el que se hace el comercio activo y pasivo desde los puertos de mar hasta los interiores del Reino, a los gravámenes y trabajos impracticables en parte alguna del mundo, pero [folio 746r.] que lo omite remitiéndose a las respuestas dadas por el señor regidor juez subdelegado de bienes de difuntos Don Josef Martínez Troncoso y Doña Manuela Gutiérrez a la notificación que se les hizo en diez y ocho del expresado mes de febrero de mil ochocientos cinco del citado superior despacho y auto de su obedecimiento proveído por los señores alcaldes ordinarios de aquel año, y ratificando además la respuesta que tiene dada en doce de marzo del pasado año de mil setecientos noventa y dos a la notificación que entonces se le hizo del superior despacho librado también a solicitud de los diputados del mismo comercio en aquel tiempo que con las diligencias en su virtud practicadas como en el expediente la cual para la determinación suplica se traiga a la vista que el conservará sus embarcaciones en el [----] como lo ha hecho a más de treinta años a esta parte siempre que le traiga cuenta y no le sean gravosas por las trabas o gravámenes que se le impongan y no de otro modo y en tal virtud omite por su parte más del derecho del emplazamiento y la firma doy fe Ramón del Corral y Castro - Ledezma 
Seguidamente notifiqué el proveído antecedente a Don Justo Piñeiro, e impuesto de su contenido dijo [folio 746v.] que en asunto de que trata el presente expediente no se considera parte de modo alguno; tanto porque los champanes que maneja no son propios sino de la pertenencia de Don Miguel Hernández vecino de Girón; cuanto porque ellos están destinados a navegación extraña, cual es la del rio de Sogamoso a Mompox y de esta villa al dicho Sogamoso, conduciendo solo los frutos que salen por aquellas bodegas desde lo interior del Reino por Girón, sin otra intervención al exponente que recibir el número de cargas que se le consignan, dar cuenta al interesado y pagar bogas para que regresen dichos champanes que únicamente se a reducen dos, que estos no han tenido ni tienen que ver nada con el tráfico de Cartagena para Honda Y lo firma Justo Piñeiro - Ledezma

Inmediatamente notifiqué el proveído antecedente a Don Melchor Sáenz Ortíz, quien impuesto dijo que en el particular de que tratan las diligencias antecedentes en manera alguna es parte, por no tener champanes de su pertenencia pues aunque corre con los de Don Julián Meriño vecino de la villa de Honda, no es más [folio 747r.] que para suministrarles los avíos necesarios a su tránsito para Cartagena, Barranca y retorno a dicha Villa y lo firma de que doy fe Melchor Sáenz Ortíz - Ledezma.

Certifico: que habiendo solicitado por la persona de Don Francisco de la Bárcena Posada, en su casa se dice dio por razón hallarse aun ausente de esta villa, y en la plaza de Cartagena y para que conste pongo la presente en Mompox a diez y ocho de agosto de mil ochocientos siete Carlos José de Ledezma.

Compulsase testimonio de estas diligencias en ocho fojas para resguardo de esta escribanía. Mompox doce de septiembre de mil ochocientos siete Ledezma.

[folio 748r.]

Santa Fe 2 de octubre de 1807 al señor asesor real excelentísimo señor en cumplimiento de lo prevenido por vuestra excelencia ponemos en sus manos superiores el expediente original creado sobre bogas para los efectos que haya lugar.

Dios guarde a Vuestra Excelencia muchos años, Mompox septiembre 13 de 1807

Excelentísimo Señor

Pantaleón Germán Ribón - Nicolás Valest

Excelentísimo Señor Virrey Gobernador Capitán General del Reino. [folio $749 r$.]

Santa fe octubre 3 de 1807

Sepárese del cuaderno a que viene agregado por no ser el correspondiente póngase con el respectivo y al señor fiscal.

Bustamante

Excelentísimo señor el fiscal de lo civil dice: que la solicitud de los diputados del comercio hecha en 31 de agosto de 1792, ha causado el emplazamiento que se ha hecho a los dueños de embarcaciones de Mompox cuyas diligencias son las que a[h]ora se remiten por lo que podrá vuestra excelencia mandar se 
les haga saber a el que fuere parte para que en su vista promuevan lo que fuere competente a su derecho. Santa fe Octubre 7 de 1807 - octubre 9 de 1807

Firmo como aparece al señor fiscal

Bustamante

[folio 749v.]

Diez y seis de los mismos, pasé noticia del superior auto que antecede al señor Don Diego Frías fiscal de lo civil su señoría rubrica doy fe.

\section{Mateus.}

En diez y siete de los mismos, lo hice saber a José de Vargas por el síndico procurador general de la villa de Mompox y se excusó a firmar.

Mateus

[ilegible] [ilegible]

Y 21 de octubre

Santa Fé octubre 23 de 1807

Al señor fiscal con el expediente en que obra la providencia dictada por punto general para que los procuradores formen las notificaciones de las providencias.

Bustamante.

Nota

Se acompañan 3 providencias una de 199 y las dos restantes de 563

Excelentísimo señor

El fiscal

[folio 750r.]

Lo [----] dice; que el procurador José de Vargas no debió excusarse a firmar la notificación que se le hizo del superior decreto de 9 del corriente así por ser apoderado del procurador general de la villa de Mompox según se ve de su escrito que dio motivo a las anteriores providencias como por estar mandado en el de 21 de mayo de 803 que los procuradores deben firmar las notificaciones que se les hagan exponiendo los que les convenga para salvar su responsabilidad o cualquier equivocación esta se hizo saber a el mismo Vargas y por lo mismo ha incurrido en el irrespeto que allí se trató de corregir. en esta visita conforme a la prevención que entonces se hizo, se ha de servir de determinar lo que convenga y mandar que dicho procurador conteste o promueva lo que convenga a su parte en justicia. Santa Fe, octubre 27 de 1807 Frías.

[folio 750r.] Santa Fe, octubre 30 de 1807, el receptor cumpla con lo mandado en providencia de siete de septiembre de mil ochocientos tres.

Bustamante.

En tres de noviembre de dicho año pasé noticia del antecedente superior auto al señor Don Diego Frías fiscal de lo civil: su señoría rúbrica doy fe.

Martínez

En tres del mismo mes lo hice saber al escribano receptor [ilegible] quedó impuesto. Doy fe

Mateus - Martinez

En la ciudad de Santa Fe a veinte y cuatro de noviembre de mil ochocientos y siete, yo el escribano receptor en cumplimiento del antecedente superior 
decreto notifiqué al procurador Josef de Vargas desde nueve de octubre del mismo año e impuesto dijo: [ilegible] don Francisco de la Bárcena Posada [folio 751r.] a en el año que fue procurador general de la villa de Mompox, encargó al exponente el asunto de que trata este expediente para [ilegible] solicitar el de este superior gobierno la providencia que se dictó en veinte y siete de julio de ochocientos cinco, con prevención al mismo exponente de que los asuntos promovidos como [...] procurador general los adelantaré por el tiempo que Bárcena [ilegible] 